\title{
Correction to: Not What I Expected: Training Social Work Students in Community-Based Prevention of Child Maltreatment
}

\author{
Carmit Katz $^{1}$ • Jill D. McLeigh ${ }^{2} \cdot$ Asher Ben-Arieh $^{3}$ \\ Published online: 10 September 2020 \\ (C) Springer Nature Switzerland AG 2020
}

\section{Correction to: Int. Journal on Child Malt. https://doi.org/10.1007/s42448-020-00056-4}

The original article has been corrected. A typo in the title has been corrected, so that the title now is.

Not What I Expected: Training Social Work Students in Community-Based Prevention of Child Maltreatment.

Publisher's Note Springer Nature remains neutral with regard to jurisdictional claims in published maps and institutional affiliations.

The online version of the original article can be found at https://doi.org/10.1007/s42448-020-00056-4

Carmit Katz

drckatz@gmail.com; https://orcid.org/0000-0001-6631-1141

1 Bob Shapell School of Social Work, Tel Aviv University, Ramat Aviv, 69978 Tel Aviv, Israel

2 The Kempe Center, University of Colorado Anschutz Medical Campus, Aurora, CO, USA

3 Haruv Institute, Hebrew University, Jerusalem, Israel 